Volume 20 Number 1 June 2020. p.233-251

https://doi.org/10.30603/au.v20i1.1146

\title{
The Distribution of Zakat Mal Based on Al-'Adl in Order to Improve The Welfare of The Mustahiqs in The Laznas of Baitul Mal Hidayatullah South Sulawesi
}

\author{
1.Jamaluddin, ${ }^{2} \cdot$ Irwan Misbach, ${ }^{3 \cdot A b d u l ~ W a h a b ~}$ \\ 1.2.3.Universitas Islam Negeri Alauddin Makassar, Indonesia
}

\begin{abstract}
The main problem of this research is how is the distribution of zakat mal based on al-'adl in improving the welfare of mustahiq at LAZNAS BMH South Sulawesi? This type of research is classified as qualitative with the research approach used is: theological-normative and sociological economics. The results of this study indicate that the distribution of zakat mal conducted by LAZNAS BMH South Sulawesi, there are two patterns, namely: consumptive distribution patterns and productive distribution patterns. The consumptive pattern of zakat mal is given to meet the basic needs of mustahiq, while the productive pattern is given in the form of empowering Human Resources, which is formidable preachers, poor education scholarships, empowered boarding school economics, and social community programs. Distribution of zakat is done by applying the values of justice namely; proportional justice, not tyrannical, and recognizing freedom, the distribution process always embarrasses the scale of priorities that mustahiq most need.
\end{abstract}

\begin{abstract}
Abstrak
Pokok masalah penelitian ini adalah distribusi zakat mal berbasis al-'adl dalam meningkatkan kesejahteraan mustahiq di LAZNAS BMH Sulawesi Selatan. Jenis penelitian ini tergolong kualitatif dengan pendekatan penelitian yang digunakan adalah: teologi-normatif dan sosiologis ekonomi. Hasil penelitian ini menunjukkan bahwa distribusi zakat mal yang dilakukan oleh LAZNAS BMH Sulawesi Selatan terdapat dua pola, yakni: pola distribusi konsumtif dan pola distribusi produktif. Pola distribusi konsumtif diwujudkan untuk memenuhi kebutuhan pokok mustahiq, sedangkan pola produktif diberikan dalam bentuk pemberdayaan sumber daya mustahiq yakni da'i tangguh, program pendidikan fakir miskin, program ekonomi pesantren berdaya, dan program sosial kemanusiaan. Keadilan distribusi zakat mal dilakukan dengan menerapkan keadilan proporsional (equity), keseimbangan (al-mizan), dan tidak menzalimi (al-Zulm), sehingga proses penyalurannya selalu mendalukan skala perioritas mustahiq yang paling membutuhkan.
\end{abstract}

Kata Kunci: Distribution, Zakat Mal, Al-'Adl, Welfare

Author correspondence

Email: jamaluddin26@rocketmail.com, irwan.misbach@uin-alauddin.ac.id, Abdulwahab210472@gmail.com _Available online at http://journal.iaingorontalo.ac.id/index.php/au/index 


\section{A. Introduction}

Islam has governed all aspects of human life, including in the economic field. One of its goals is to realize justice and equity in the distribution of assets, both in the lives of individuals and in social life. Distribution is a way to distribute wealth or be given to several factors of production that contribute to individuals, society and the country. ${ }^{1}$

Muslims are ordered to distribute a portion of the assets that have been obtained to meet the needs of the needy, poor, travelers, and prohibitions apply wasteful. This means of distribution in Islam is known as zakat, infaq, and alms. ${ }^{2}$ The provisions in the Qur'an and Sunnah regarding the obligation to issue zakat for humanity are proof of how Islam prioritizes the prosperity of human life. Zakat reflects that life must be in harmony and complement each other, the system of life, the economy does not create the rich to enrich themselves and vice versa. ${ }^{3}$

Abdul Mannan's thought regarding the distribution of income is his concern in preventing the concentration of wealth in a group of people with a number of operational policy packages implemented, both mandatory and voluntary. One of the instruments used is the payment of zakat, Mannan considers that zakat is the main source of state revenue, but is not seen as a tax but rather as a religious obligation, namely as one of the pillars of Islam. For this reason, zakat is the financial axis of an Islamic state. Zakat is permanent and the recipients have also been determined (asnaf eight). Zakat is a form of distribution of assets that can eliminate social inequality among people who have a weak economic level. ${ }^{4}$

The distribution of income and circulation of wealth is very influential on people's welfare. This is in line with the basic objectives of Islam, which is to want the welfare of adherents in the world and happiness in the afterlife, this can be

\footnotetext{
${ }^{1}$ Hamidy Thalib dkk, "Amil's Role as Manager of Zakat to Improve People's Welfare in the City of Bima”, Iqtishadia 3, no. 2 (2016): p. 291.

${ }^{2}$ Idris, Hadis Ekonomi: Economics in the Perspective of the Prophet's Hadith (Cet ke-1; Jakarta: Prenada Media Group, 2015), p. 130.

${ }^{3}$ Hebby Rahmatul Utami, "Economic Justice in the Distribution of Zakat by the Amil Zakat Agency, Tanah Datar District”, Tamwil 1, no. 2 (2015): p. 1.

${ }^{4}$ Abdul Mannan, Theory and Practice of Islamic Economics (Cet. Ke-3: Yogyakarta: PT. Dana Bhakti Prima Yasa, 1997), p. 112.
} 
The Distribution of Zakat Mal Based on Al-'Adl in Order to Improve The Welfare of The Mustahiqs in The Laznas of Baitul Mal Hidayatullah South Sulawesi

realized if the basic needs (basic needs) of the community can be met properly so that there is no gap between the rich and the poor. ${ }^{5}$

This is in accordance with the principle of maqăsid al-shariah which is to realize the benefit of society by eliminating all things that lead to damage (mafsadah). Therefore, Islam strives to uphold distribution justice to the community, because God strongly condemns the distribution of assets which are only concentrated in a handful of people, this is explained by Allah in the QS. alHasyir/ 59: 7.

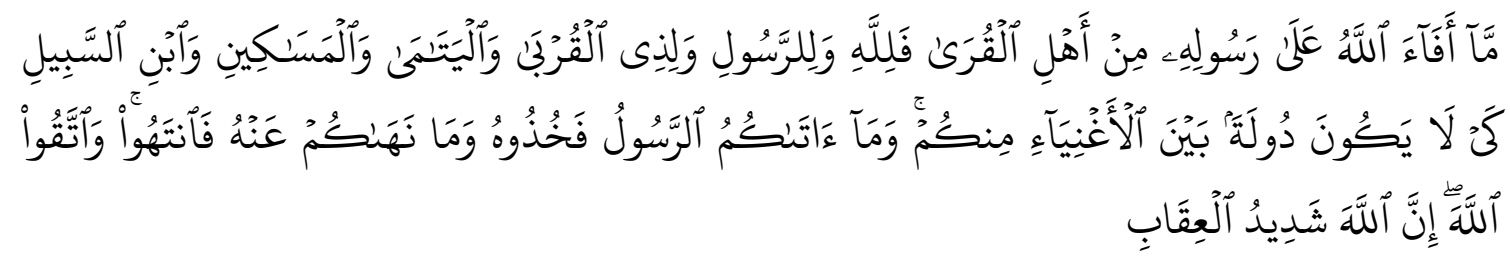

Translation:

Whatever booty (fai-i) that Allah gives to His Messenger (from property) that comes from the inhabitants of the cities is for Allah, for the Apostles, relatives, orphans, poor people and people those who are on their way, that the treasure should not be circulated among the rich among you. What the Apostle gave you, then accept it. Leave what he forbids. And fear Allah. Surely Allah is severely punished. ${ }^{6}$

According to the Quraish Shihab, the verse intends to emphasize that property should not only belong to and belong to a group of people, property must be circulated in the community so that it can be enjoyed by everyone while still recognizing ownership rights and prohibiting monopoly because from the beginning Islam stipulated that property have social functions. ${ }^{7}$

According to Eko Sugiharto in his research explained that the indicators used to determine the level of welfare include; family income, consumption or expenses, living conditions, housing facilities, health of family members, easy access to health services, ease in getting children into education, and easy access to transportation facilities. ${ }^{8}$

\footnotetext{
${ }^{5}$ Nadya Rahmi, “Realizing Community Welfare Through Distribution Justice”, Jurnal Pulikasi 1, no. 1 (2018): p. 24.

${ }^{6}$ Kementerian Agama RI, Al-Qur'an and Translation (Yogyakarta: Dar al-Fikr, 2015), p. 546.

${ }^{7}$ M. Quraish Shihab, Tafsir al-Misbah, Vol. 4 (Jakarta: Lentera Hati, 2002), p. 112.

${ }^{8}$ Eko Sugiarto, "Welfare Level of Fishermen Community of Benua Baru Ilir Village Based on Statistics Indonesia", EPP 4, no. 2 (2007): p. 32.
} 
The well-being (maslahah) of a society depends on the search and maintenance of five basic objectives, namely religion (din), life or soul (nafs), family or offspring (nasl), wealth or wealth ( $\mathrm{mal}$ ), and intellect or reason ('aql ). Material and spiritual well-being is a goal to be achieved in the development process, this shows that the success of development must be achieved not only in the material aspect alone, but also in the spiritual aspect. ${ }^{9}$

The distribution of zakat with the concept of justice becomes one of the most strategic instruments for mental development and also the solidarity of every human being to reduce (minimize) the gap between groups of people who have abundant wealth and groups of people living below the poverty line. ${ }^{10}$

Economic justice in Islam is understood as the implementation of the act of not wronging and not being wronged, that is, there is no mafsadah, there is no garar, no maysir, and does not contain usury. Actualization of the value of justice as a practice in Islamic economics can be described in the principles of justice in it, namely the realization of equality, equity and rights and obligations. ${ }^{11}$

Zakat is maliyah ijtima'iyyah worship, where zakat has a very important, strategic and decisive position, both in terms of Islamic teachings and in terms of the development of the welfare of the people. ${ }^{12}$ Zakat is an act of worship that is not only reflected in the payment of property, but also involves spiritual purification and ownership.

Zakat aims to solve various kinds of social problems such as unemployment, poverty, and the means of income distribution to achieve social justice. ${ }^{13}$ Zakat distribution system is a solution to these problems by providing assistance to the poor regardless of race, color, ethnicity and other worldly attributes. It can also be

\footnotetext{
${ }^{9}$ Harry Hikmat, Community Empowerment Strategy (Bandung: Humaniora Utama Press, 2010), p. 8.

${ }^{10}$ Wahbah al Zuhaily, Al-Fiqh Al-Islamiy wa Adillatuhu, Jilid II (Damsyiq: Dar Al-Fikr, 1989), p. 732.

${ }^{11}$ Arfin Hamid, Islamic Economic Law in Indonesia: Applications and Prospects (Bogor: Ghalia Indonesia, 2007), p. 121.

${ }^{12}$ Didin Hafidhudin, Zakat in Modern Economy (Jakarta: Gema Insani Press, 2002), p. 45.

${ }^{13}$ Hasanuz Zaman, Islamic Criteria for the Distribution of Tax Burden (The Mix of Direct and Indirect Taxes the Offsetting Fuction of Zakat), Journal of Islamic Economics 3, no. 1 (1993): p. 95.
} 
The Distribution of Zakat Mal Based on Al-'Adl in Order to Improve The Welfare of The Mustahiqs in The Laznas of Baitul Mal Hidayatullah South Sulawesi

seen as a form of purification and cleansing of its assets. ${ }^{14}$ According to the word of God in QS. Al-Taubah /9: 103 as follows:

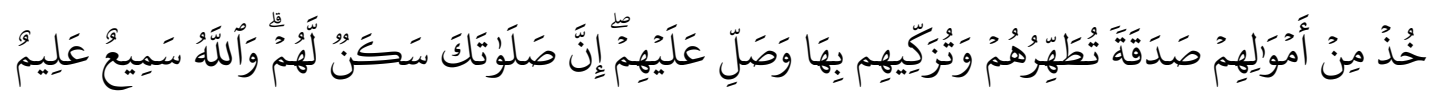

Translation:

Take alms from some of their assets, with that you cleanse and purify them and pray for them. Verily, your prayers (become) peace of mind for them. And Allah is All-Hearing, All-Knowing. ${ }^{15}$

Problems that often arise in society about zakat are still based on classical fiqh understanding, lack of public trust in institutions. ${ }^{16}$ Community trust in zakat institutions formed by certain communities or organizations is much stronger compared to institutions formed by the government. ${ }^{17}$

The emphasis in solving economic problems is to create a mechanism of distribution of al-'adl based in the middle of society, distribution in the Islamic economy means ownership, elements of production, and sources of wealth. ${ }^{18}$ The substance of economic building is related to the goal of implementing the value of justice and balance (equilibrium), a framework of justice also greatly enables all people to have the opportunity and benefits of the allocation of development that takes place proportionally. ${ }^{19}$

One of the amil zakat institutions which have their attention and empowerment on micro economics and social economy is Baitul Mal Hidayatullah (BMH) South Sulawesi. Attention Baitul Mal Hidayatullah in empowerment is illustrated by various programs such as; empowerment of converts, orphans, national disaster preparedness and also spread of the archipelago. Baitul Mal Hidayatullah is a National Amil Zakat Institute (LAZNAS) which is engaged in collecting zakat, infaq, alms, endowments, and grants, along with humanitarian

\footnotetext{
${ }^{14}$ Hasanuz Zaman, Islamic Criteria for the Distribution of Tax Burden (The Mix of Direct and Indirect Taxes the Offsetting Fuction of Zakat), Journal of Islamic Economics 3, no. 1 (1993): p. 95.

${ }^{15}$ Kementerian Agama RI, Al-Qur'an and Translation, p. 203.

${ }^{16}$ Taqiyullah H.O, Zakat and Community Economic Empowerment (Bandung: BAZ Provinsi Jabar, 2004), p. 7.

${ }^{17}$ Anonim, "Appreciating the Rise of Civil Society in Managing Zakat in Indonesia", Jurnal Pemikiran dan Gagasan 1, no. 4 (2008): p. 70.

${ }^{18}$ Rozalinda, Islamic Economics: Theory and Its Application in Economic Activity (Jakarta: Raja Grafindo Persada, 2014), p. 131

${ }^{19}$ Euis Amalia, Distribution Justice in Islamic Economy, Strengthening the Role of LKS and SMEs in Indonesia (Jakarta: Raja Grafindo Persada, 2009), p. 117.
} 
social funds and Corporate Social Responsibility (CSR) companies, and distributes through education programs, preaching, social humanitarianism, and the national economy. ${ }^{20}$

Similarly is done by LAZNAS BMH Representatives South Sulawesi with good efforts to provide facilities and infrastructure for its members to develop and empower businesses that are managed, so as to provide positive value both themselves and to other communities and the nation.

\section{B. Result and Discussion}

The distribution of zakat funds in general by LAZNAS BMH South Sulawesi is channeled towards consumptive and productive patterns. In consumptive terms, it is realized to fool'fill the basic needs of mustahiq, such as the distribution of zakat in the form of educational scholarship assistance for orphans, social assistance to poor families for food, treatment and health. ${ }^{21}$

While in the distribution of zakat mal the productive pattern is carried out in the form of empowering human resources and providing capital assistance for the development of productive businesses, also manifested for social humanitarian programs. This program is more directed at mustahiq empowerment, because in the utilization of zakat this pattern aims for the long term in order to improve the welfare of mustahiq. ${ }^{22}$

In addition, the use of zakat funds can be distributed through traditional consumptive patterns, namely zakat given to mustahiq directly for daily consumption, such as the distribution of zakat fitrah in the form of basic necessities and distribution of zakat assets to buy a number of desired needs. This pattern is a short-term program because the zakat funds are not developed in the things that can produce, the goal is only to overcome problems that occur in the community.

Furthermore, the conventional productive pattern, namely zakat given in the form of productive goods, where by using these items the mustahiq can create

\footnotetext{
${ }^{20}$ www.bmh.or.id, accessed March 13, 2019.

${ }^{21}$ Results of Interview with Syamsuddin as Head of Division of LAZNAS BMH Empowerment South Sulawesi conducted on October 9, 2019

${ }^{22}$ Results of Interview with Syamsuddin as Head of Division of LAZNAS BMH Empowerment South Sulawesi conducted on October 9, 2019
} 
The Distribution of Zakat Mal Based on Al-'Adl in Order to Improve The Welfare of The Mustahiqs in The Laznas of Baitul Mal Hidayatullah South Sulawesi

their own business. Such productive items such as goats, laying hens, sewing machines, and carpentry tools. Then the distribution of zakat with creative productive patterns namely zakat is realized by providing revolving business capital, both for capital of social projects, as well as other business development aimed at traders and small entrepreneurs, the main purpose of this zakat distribution pattern is to make mustahiq as a muzakki in the future. ${ }^{23}$

The form of zakat distribution conducted by LAZNAS BMH South Sulawesi can basically be classified into two, namely consumptive and productive distribution. Consumptive distribution such as provision of food, clean water assistance, and assistance to people traveling who run out of provisions. Whereas productive distribution is manifested in the form of empowerment of mustahiq through a formidable da'i empowerment program, the granting of scholarship to memorizing the Qur'an, and helping the poor. ${ }^{24}$

Utilization of zakat can be devoted to consumptive needs. ${ }^{25}$ Consumptive Zakat is the distribution of zakat in the form of direct funds in the form of compensation as a form of fulfilling the basic needs of mustahiq. Temporary assistance does not mean that zakat is only given to mustahiq once. But the distribution is not accompanied by the target of economic independence for the mustahiq. This is done because the mustahiq concerned is no longer possible to be independent such as elderly people, disabled people, displaced refugees or victims of natural disasters. ${ }^{26}$

Some forms of productive zakat empowerment programs developed by LAZNAS BMH South Sulawesi so far in order to provide welfare to mustahiq, the program actually has been referring to the utilization contained in the National Amil Zakat Agency. The programs in question include tough $d a^{\prime} i$ empowerment

\footnotetext{
${ }^{23}$ The results of an interview with Kadir as chairman of LAZNAS BMH South Sulawesi held on October 9, 2019.

${ }^{24}$ Results of Interview with Syamsuddin as Head of Division of LAZNAS BMH Empowerment South Sulawesi conducted on October 9, 2019

${ }^{25}$ Rusli, dkk, "Impact Analysis of Productive Zakat Capital on Poverty Alleviation in North Aceh District", Jurnal Ilmu Ekonomi 1, no. 1 (2013): p. 58.

${ }^{26}$ Hertanto Widodo dan Teten Kustiawan, Accounting and Management for Zakat Management Organizations (Ciputat: Institut Manajemen Zakat, 2001), p. 84.
} 
program, poor education scholarships, boardig school economic programs, and social humanity program. ${ }^{27}$

\section{Tough da'i empowerment program}

Tough da'i program are aimed at facilitating preachers deployed in remote areas that are still difficult to reach. Utilization of this program in the form of benefits for $d a^{\prime} w a h$ that dedicates his life to $d a^{\prime} w a h$, transportation facilities such as cars, and speedboats to reach remote areas, life skills training, insurance, umrah awards to preachers, program guidance for converts and endowments of the Qur'an.

LAZNAS BMH South Sulawesi has sent around 30 preachers deployed to various remote areas. One form of empowerment for them is the provision of zakat funds to meet their needs with their families. Through this empowerment, this is expected to be able to provide a change in society, especially in terms of fostering Islamic treasures. ${ }^{28}$

The results of the $d a^{\prime} i$ empowerment carried out by LAZNAS BMH South Sulawesi have been seen with high commitment. One example of the success of this formidable $d a^{\prime} i$ program in Pangkep Regency. After being sent from a formidable preacher to the area, no community came to the mosque to perform a congregation, after the preacher was assigned to the area, slowly the community began to enliven the mosque and the local community directed their children to get religious education such as learning offer prayers, read the Koran, study, and develop religion thoroughly. ${ }^{29}$

Ahmad Harun is one of the preachers who have been empowered by LAZNAS BMH South Sulawesi, he said that as long as he became part of the formidable preacher program he had felt a lot of assistance from LAZNAS BMH South Sulawesi, such as guarantees of daily needs, costs of coaching students, education building construction costs etc. All this time LAZNAS BMH South

\footnotetext{
${ }^{27}$ Results of Interview with Syamsuddin as Head of Division of LAZNAS BMH Empowerment South Sulawesi conducted on October 9, 2019.

${ }^{28}$ Results of Interview with Syamsuddin as Head of Division of LAZNAS BMH Empowerment South Sulawesi conducted on October 9, 2019.

${ }^{29}$ Results of Interview with Syamsuddin as Head of Division of LAZNAS BMH Empowerment South Sulawesi conducted on October 9, 2019.
} 
The Distribution of Zakat Mal Based on Al-'Adl in Order to Improve The Welfare of The Mustahiqs in The Laznas of Baitul Mal Hidayatullah South Sulawesi

Sulawesi has been the main support in giving alms funds. And he felt that so far LAZNAS BMH South Sulawesi had been prospered. ${ }^{30}$

Meanwhile, according to Kahar Mussakar, the amount of funds currently received from LAZNAS BMH South Sulawesi reaches 10 million per month in the form of basic needs and all the consumption costs of the students at the boarding school and the operational costs of the boarding school. While the needs in the form of food are provided directly from LAZNAS BMH South Sulawesi such as rice, side dishes and so forth. According to him, the measure of prosperity is when sincere in carrying out all the mandates of the institution, there is no disruption in worship, there is calm in carrying out routine worship to God. ${ }^{31}$

The following is a list of respected $d a^{\prime} i$ names assigned to various regions in South Sulawesi.

\begin{tabular}{|c|l|c|}
\hline No & \multicolumn{1}{|c|}{ The name is tough da'i } & Placement area \\
\hline 1 & Ahmad Harun & Kec. Pucak, Maros \\
\hline 2 & Kahar Mussakar & Kec. Pucak, Maros \\
\hline 3 & Anwar Baits & Kab. Pinrang \\
\hline 4 & Abdullah & Kec. Bacukiki Barat Pare-Pare \\
\hline 5 & Mardhatillah & Tamalanrea \\
\hline 6 & Massiara & Belopa, Kab. Luwu \\
\hline 7 & Abd Jabbar & Pare-pare \\
\hline 8 & Syarifuddin & Kec. Taneta Riattang, Bone \\
\hline 9 & Ismail Muchtar & Kec. Alla, Enrekang \\
\hline 10 & Restu & Tamalanrea \\
\hline 11 & Sumariadi & Kec. Moncongloe, Maros \\
\hline 12 & Syamsuddin & Kec. Burau, Luwu Timur \\
\hline 13 & Lukmanul Hakim & Kec. Lilirilan, Soppeng \\
\hline 14 & Muhammad Arif & Tamalanrea \\
\hline 15 & Alyas & Mamuju \\
\hline 16 & Abd Aziz & Kec. Barebbo, Bone \\
\hline 17 & Hamzah & Barru \\
\hline 18 & M. Arif Al Hudzaie & Tamalanrea \\
\hline 19 & Abdul Majid & Kiawa, Sidrap \\
\hline 20 & Abdul Samad & Mec. \\
\hline
\end{tabular}

\footnotetext{
${ }^{30}$ The results of an interview with Ahmad Harun, one of the tough preachers who have been empowered by LAZNAS BMH South Sulawesi on October 15, 2019

${ }^{31}$ Interview with Kahar Mussakar, one of the most respected preachers placed at the Ummul Qura boarding school 'Tompobulu Maros Regency on 17 October 2019.
} 


\begin{tabular}{|l|l|c|}
\hline 21 & Fijar Ali Fatih & Kec. Belopa, Luwu \\
\hline 22 & Nadjamuddin & Kec. Tomuti, Luwu Timur \\
\hline 23 & Burhanuddin & Tamalanrea \\
\hline 24 & Karding & Kec. Subulue, Bone \\
\hline 25 & Burhan & Kec. Pitu Riawa, Sidrap \\
\hline 26 & Jumawir & Telluwanue, Palopo \\
\hline 27 & Irfan Yahya & Kec. Pattallassang, Gowa \\
\hline 28 & Sukron Amin & Kec. Mare, Bone \\
\hline 29 & Mukhsin & Kec. Towati, Luwu Timur \\
\hline 30 & Matopo Abd Wahab & Masamba, Luwu Utara \\
\hline
\end{tabular}

\section{The poor education programs}

This program was launched through careful consideration, starting from family income, housing conditions, and dependents of children, this was done so that the zakat funds distributed to them were efficient and well targeted. Because the main purpose of the essence of zakat is to lift the dignity and dignity of the recipient, be able to take proper education, lighten the burden of life, and be able to be productive in the long run.

A similar sentiment was expressed by Kadir, leader of LAZNAS BMH South Sulawesi, that one of the forms of empowerment carried out was to produce Human Resources, because if the poor were included in the eight ASNAF, they could be empowered in the form of providing education funding, then he would later be a human being who had a good future in terms of opportunities to get a job, and if you have got a good job then he has prospered. In addition, when you have a high education, it is free from various forms of ignorance and has good scientific treasures. ${ }^{32}$

Therefore, according to Kadir that welfare is not only measured by the high income in terms of financial but can also be measured from the level of one's education, making mustahiq be productive not only seen than giving funds to be managed into a business that produces in the future, but the giving of zakat funds

${ }^{32}$ The results of an interview with Kadir as chairman of LAZNAS BMH South Sulawesi held on October 9, 2019. 
The Distribution of Zakat Mal Based on Al-'Adl in Order to Improve The Welfare of The Mustahiqs in The Laznas of Baitul Mal Hidayatullah South Sulawesi

to mustahiq in the form of education is far more promising because it is related to life in the long run. ${ }^{33}$

The efforts made by LAZNAS BMH South Sulawesi in distributing zakat funds can be done in several ways; First, poor people who come directly to the office to register for scholarship assistance for their children so they can go to school. Second, LAZNAS BMH South Sulawesi itself is looking for needy or poor people to orphanages and villages that do not go to school because they are constrained by the cost of education.

This program is intended to deliver the nation's cadres in achieving a better future with an education empowerment program. The education program includes:

a) Scholarship to care for orphans and duafa

The foundation underlying success after the religious factor is education. Education in every region in Indonesia is a problem that is difficult to solve, many factors inhibit a child and family with middle to lower economic income and even less able to continue their education to a higher level. One obstacle is not because the child is lazy to learn, but rather the high school fees that must be spent, while family income does not meet these costs. To overcome this problem, in fact the Qur'an has provided the best solution as the word of God in the QS. Al-Maidah/5: 2.

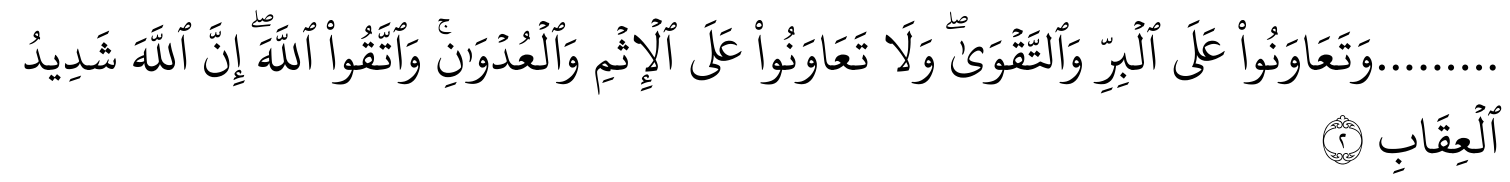

Translation:

And please help you in (doing) virtue and piety, and don't help in committing sins and transgressions. And fear Allah, verily Allah is severely tortured. ${ }^{34}$

The verse expressly gives a signal to humans to always practice the principle of helping in this life, including helping in helping others in terms of school education costs. So, LAZNAS BMH South Sulawesi as a zakat institution is

\footnotetext{
${ }^{33}$ The results of an interview with Kadir as chairman of LAZNAS BMH South Sulawesi held on October 9, 2019.

${ }^{34}$ Kementerian Agama RI, Al-Qur'an and Translation, p. 106.
} 
present as a facilitator and solution to various problems in the community, especially the problem of education.

One of the programs from LAZNAS BMH South Sulawesi, namely providing compensation in the form of financial assistance intended to support and ease the cost of education for those who are less able. LAZNAS BMH South Sulawesi has fully borne the education costs of the people of duafa, at least this is a very good initial step for example for other zakat institutions, and this is evidence of the implementation of the Qur'anic injunction about helping in matters virtue. ${ }^{35}$

In interviews with several students of duafa who received scholarship assistance they said that it was greatly helped by the assistance from LAZNAS BMH South Sulawesi, in fact all their needs had been borne by LAZNAS BMH South Sulawesi, such as the consumption of students, provision of free dormitories, and capacity building. Syahrul mubarak is one of the students who revealed that so far it has been helped by the assistance provided by LAZNAS BMH South Sulawesi, not burdening the parents, even so far it has been more than enough assistance provided by LAZNAS BMH South Sulawesi. ${ }^{36}$

In addition to the aid program for the duafa, there is also a scholarship program for memorizing Qur'an intended for orphans and poor people who want to memorize Qur'an 30 thirty, starting from junior high school to high school level, which is located at Qur'an Tanralili House, Maros District. This program aims to foster children that lead to the empowerment of children's potential in the religious field, especially in memorizing the Qur'an.

b) Tahfiz Qur'an scholarship

The Qur'an's tahfiz assistance program, students received scholarship assistance from LAZNAS BMH South Sulawesi which was handed over to the management of the House of Qur'an to finance all the operational educational needs of the students. In this program, every student who gets a scholarship from tahfiz is a Muslim boarding school for the House of the Qur'an specifically for the

\footnotetext{
${ }^{35}$ Results of Interview with Syamsuddin as Head of Division of LAZNAS BMH Empowerment South Sulawesi conducted on October 9, 2019

${ }^{36}$ Direct Interview with Syahrul Mubarak and Muhammad Asril as beneficiaries/mustahiq from October 17, 2019 at the Ummul Qura Islamic Boarding School 'Pucak, Maros
} 
The Distribution of Zakat Mal Based on Al-'Adl in Order to Improve The Welfare of The Mustahiqs in The Laznas of Baitul Mal Hidayatullah South Sulawesi

memorizers of the Qur'an. ${ }^{37}$ As is the case with scholarships for community members, the forms of assistance are daily needs and capacity building.

Data on students receiving scholarships for tahfiz Qur'an

\begin{tabular}{|c|c|c|}
\hline No & Educational stage & The number of mustahiq \\
\hline 1 & SMP & 45 People \\
\hline 2 & SMA & 63 People \\
\hline \multicolumn{2}{|c|}{ Total Jumlah Mustahiq } & 108 People \\
\hline
\end{tabular}

\section{Boarding school economic empowerment program}

This economic program is in the form of providing capital assistance to certain boarding school which have strategic locations for developing boarding school based economies. One form of this program is pepper plantations located in East Luwuk, where all capital, maintenance costs and others are all accommodated by LAZNAS BMH South Sulawesi. The aim is to help poor families who are around the boarding school taken from the plantation. ${ }^{38}$

Improving the performance of businesses belonging to disadvantaged people is essentially a shared responsibility between the government and the community with various problems and capital constraints, lack of managerial skills, low technology, and limited market access resulting in zakat management institutions must be truly selective in choosing businesses that want to developed by looking at opportunities to last a long time and be able to meet the needs in the future. So, this boarding school economic program in the form of pepper plantations is a promising long-term program and can provide many benefits to boarding school especially the surrounding community. ${ }^{39}$

Various efforts and efforts made by LAZNAS BMH South Sulawesi in distributing zakat funds to mustahiq with various objectives both for the capital of the boarding school economic development and for the improvement of small businesses. Since its presence in the midst of the people of South Sulawesi, it has helped many people in their efforts to empower them through productive efforts.

\footnotetext{
${ }^{37}$ Results of Interview with Syamsuddin as Head of Division of LAZNAS BMH Empowerment South Sulawesi conducted on October 9, 2019

${ }^{38}$ Results of Interview with Syamsuddin as Head of Division of LAZNAS BMH Empowerment South Sulawesi conducted on October 9, 2019

${ }^{39}$ Results of Interview with Syamsuddin as Head of Division of LAZNAS BMH Empowerment South Sulawesi conducted on October 9, 2019
} 
Various approaches taken by all levels of management in order to improve performance through existing empowerment programs.

The following is a list of LAZNAS boarding schools based on BMH South Sulawesi.

\begin{tabular}{|c|l|c|}
\hline No & \multicolumn{1}{|c|}{ The name program } & Area program \\
\hline 1 & Pepper plantations & Masamba (Luwuk Timur) \\
\hline 2 & Ecotourism program & Pucak, (Maros) \\
\hline 3 & Agricultural equipment assistance & Dusun Sombala (Maros) \\
\hline
\end{tabular}

\section{Social humaninty program}

The social programs undertaken by LAZNAS BMH South Sulawesi are incidental such as natural disaster relief, mosque construction, and other social empowerment uses. Social programs can also be carried out by helping the poor and also the elderly by providing assistance directly to the zakat funds when deemed most in need, giving alms assistance can be done in the form of staple food or in the form of material. 40

This program aims to help alleviate the burden of life even if it is only temporary. It is expected that with the help of the zakat funds, the poor and also aged people will not feel discouraged and their dignity can be elevated. From the aspect of disaster management conducted by LAZNAS BMH South Sulawesi so far, it is also expected to be able to be helped and revive after the disaster they experienced. In this program LAZNAS BMH South Sulawesi also provides guidance when there are communities affected by disaster, such as providing motivation, indicting, and assisting them until their health returns again. ${ }^{41}$

The following is a list of targets for the distribution of zakat funds with social programs.

\begin{tabular}{|c|l|l|}
\hline No & \multicolumn{1}{|c|}{ Target } & \multicolumn{1}{c|}{ Impormation } \\
\hline 1 & The poor & $\begin{array}{l}\text { Given to the poor who are economically } \\
\text { disadvantaged families }\end{array}$ \\
\hline 2 & Elderly & $\begin{array}{l}\text { Given to elderly people and also to widows who } \\
\text { are no longer able to work in meeting their daily }\end{array}$ \\
\hline
\end{tabular}

\footnotetext{
${ }^{40}$ Wawancara Langsung dengan Syamsuddin Kadiv Program Pemberdayaan Masyarakat yang dilakukan di Kantor LAZNAS BMH Sulawesi Selatan pada tanggal 09 Oktober 2019.

${ }^{41}$ Results of Interview with Syamsuddin as Head of Division of LAZNAS BMH Empowerment South Sulawesi conducted on October 9, 2019
} 
The Distribution of Zakat Mal Based on Al-'Adl in Order to Improve The Welfare of The Mustahiqs in The Laznas of Baitul Mal Hidayatullah South Sulawesi

\begin{tabular}{|c|l|l|}
\hline & & needs \\
\hline 3 & Disaster alert & $\begin{array}{l}\text { Given to those affected by natural disasters such } \\
\text { as earthquakes, landslides, floods and other } \\
\text { disasters. }\end{array}$ \\
\hline 4 & Worship facilities & $\begin{array}{l}\text { Assistance is used for the construction of the } \\
\text { mosque as a place of worship with the aim of } \\
\text { developing da'wah in that place. }\end{array}$ \\
\hline
\end{tabular}

\section{The distribution of zakat mal based on al-'adl}

Justice in the distribution of zakat is a condition that does not favor one group (asnaf) or only certain groups in the economy, so that creating justice is a loyal obligation of humans that cannot be avoided in Islam. ${ }^{42}$ Whereas true social justice is a condition that prioritizes parallels marked by high levels of income or wealth in the social system. ${ }^{43}$

Some forms of al-'adl applied by LAZNAS BMH South Sulawesi in improving the welfare of mustahiq, include:

a) Proportional Distribution Justice (al-Qist)

Each mustahiq has different needs, there are those who have large, moderate, and even those with few needs. One of the implementation of zakat distribution conducted by LAZNAS BMH South Sulawesi is distributing zakat by prioritizing the mustahiq who need it most and providing zakat funds according to their needs. If their needs are high then the portion of zakat they receive is also large, conversely if the need is low, then the amount of zakat unds given is also small. 44

The importance of comparing the proportions of inputs or outputs in distribution justice is also reflected in the definition delivered by Bartol which states that distribution justice is an assessment of equity in the proportion between outcomes received by individuals with input given compared to the proportions of inputs and results received by others. This definition indicates the

\footnotetext{
${ }^{42}$ The results of an interview with Idris as chairman of LAZNAS BMH South Sulawesi held on October 29, 2019.

${ }^{43}$ Muhammad Muslehuddin, Philosophy of Islamic Law and Orientalist Thought: Comparative Study of the Islamic Law System (Yogyakarta: PT. Tiara Wacana, 1991), p. 77.

${ }^{44}$ Wawancara terbuka dengan Kadir selaku ketua LAZNAS BMH Sulawesi Selatan yang dilakukan pada tanggal 09 Oktober 2019.
} 
proportional system (equity) which is very popular in western countries and which became the initial concept of fairness of distribution. ${ }^{45}$

b) Equilibrium (al-Mizan)

The horizontal dimension of Islam is equilibrium, which demands the realization of a balanced society with parallels that encapsulate most Islamic ethical teachings, including the distribution of wealth and income, the necessity of helping the poor in need, the necessity of making adjustments in the spectrum of distribution, production and consumption relations. This principle requires a straight path by creating a social order that avoids extremist behavior. ${ }^{46}$

LAZNAS BMH South Sulawesi always tries to distribute zakat mal funds equally and evenly to all remaining donors. However, the distribution certainly prioritizes the mustahiq that is considered most in need of assistance, this is done so that all mustahiq can feel and enjoy the collected zakat funds. Thus the gaps that often occur in society because they are not treated fairly can be overcome properly. 47

c) Not mistreat (al-Zulm)

Islam has its own meaning in interpreting justice with the term "la tazlimuna wa latuzlimun" meaning "not to wrong and not to be wronged with each other". Justice in the distribution of zakat is a condition that does not favor one group (asnaf) or only certain groups in the economy, so that creating justice is a loyal obligation of humans that cannot be avoided in Islam. ${ }^{48}$

Fairness in distribution can be interpreted as a fair distribution of income and wealth in accordance with norms of fairness that can be universally accepted. Whereas true social justice is a condition that prioritizes parallels marked by high levels of income or wealth in the social system. ${ }^{49} \mathrm{Al}-{ }^{-} \mathrm{adl}$ in distribution requires a

\footnotetext{
${ }^{45}$ Euis Amalia, Keadilan Distributif Dalam Ekonomi Islam Dalam Penguatan Peran LKM dan UKM di Indonesia, h. 57.

${ }^{46}$ Muhammad Shyarif, Ethics and Economics an Islamic Synthesis. terj. Etika dan Ilmu Ekonomi, h. 35.

${ }^{47}$ Hasil wawancara dengan Syamsuddin selaku Kadiv program pemberdayaan LAZNAS BMH Sulawesi Selatan pada tanggal 09 Oktober 2019.

${ }^{48} \mathrm{Hasil}$ wawancara dengan Idris selaku personalia di LAZNAS BMH Sulawesi Selatan yang dilakukan pada tanggal 29 Oktober 2019.

${ }^{49}$ Muhammad Muslehuddin, Filsafat Hukum Islam dan Pemikiran Orientalis: Studi Perbandingan Sistem Hukum Islam (Yogyakarta: PT. Tiara Wacana, 1991), h. 77.
} 
The Distribution of Zakat Mal Based on Al-'Adl in Order to Improve The Welfare of The Mustahiqs in The Laznas of Baitul Mal Hidayatullah South Sulawesi

condition that can guarantee the creation of equal opportunities for everyone to try to achieve something they want according to their abilities, but does not demand the same results from the process. Not justifying the accumulation of wealth that goes beyond the limits of reasonableness and keeps it within reasonable limits..$^{50}$

\section{Conclusion}

The distribution of zakat mal conducted by LAZNAS BMH South Sulawesi is manifested in two forms, namely consumptive and productive. Consumptive form is given to mustahiq in the form of primary needs assistance, while productive is realized in the form of mustahiq resource empowerment program especially for those who are classified as poor and needy. As for the forms of empowerment, they are tough $d a^{\prime} i$ empowerment program, poor education programs, boarding school economic programs, and social humanity programs.

The distribution of zakat mal based on al-'adl is the applied at LAZNAS BMH South Sulawesi, among others; first; proportional distribution justice (al-Qist) one of the teachings in Islamic economics is recognizing the scale of prioritization in distribution. Second, equilibrium (al-Mizan) in the sense of not discriminating between the mustahiq with one another. Third, not mistreat (al-Zulm) means to not side with one of the Asnaf groups, but to distribute it evenly.

\section{REFERENCES}

Al-Zuhaily, Wahbah, Al-Fiqh Al-Islamiy wa Adillatuhu, Jilid II, Damsyiq: Dar Al-Fikr, 1989.

Anonim, "Appreciating the Rise of Civil Society in Managing Zakat in Indonesia", Jurnal Pemikiran dan Gagasan 1, no. 4, 2008, p. 70.

Amalia, Euis, Distribution Justice in Islamic Economy, Strengthening the Role of LKS and SMEs in Indonesia, Jakarta: Raja Grafindo Persada, 2009.

\footnotetext{
${ }^{50}$ Hasil wawancara dengan Syamsuddin selaku Kadiv program pemberdayaan LAZNAS BMH Sulawesi Selatan pada tanggal 09 Oktober 2019.
} 
Direct Interview with Syahrul Mubarak and Muhammad Asril as beneficiaries/ mustahiq from October 17, 2019 at the Ummul Qura Islamic Boarding School 'Pucak, Maros

Hikmat, Harry, Community Empowerment Strategy, Bandung: Humaniora Utama Press, 2010.

Hamid, Arfin, Islamic Economic Law in Indonesia: Applications and Prospects, Bogor: Ghalia Indonesia, 2007.

Hafidhudin, Didin, Zakat in Modern Economy, Jakarta: Gema Insani Press, 2002.

Idris, Hadis Ekonomi: Economics in the Perspective of the Prophet's Hadith, Cet ke-1; Jakarta: Prenada Media Group, 2015, p. 130.

Interview with Kahar Mussakar, one of the most respected preachers held at the Ummul Qura boarding school 'Tompobulu Maros Regency on 17 October 2019.

Kementerian Agama RI, Al-Qur'an and Translation, Yogyakarta: Dar al-Fikr, 2015.

Mannan, Abdul, Theory and Practice of Islamic Economics, Cet. Ke-3: Yogyakarta: PT. Dana Bhakti Prima Yasa, 1997.

Muhammad Muslehuddin, Philosophy of Islamic Law and Orientalist Thought: Comparative Study of the Islamic Law System, Yogyakarta: PT. Tiara Wacana, 1991.

Rahmatul Utami, Hebby, "Economic Justice in the Distribution of Zakat by the Amil Zakat Agency, Tanah Datar District", Tamwil 1, no. 2, 2015, p. 1.

Rahmi, Nadya, "Realizing Community Welfare Through Distribution Justice”, Jurnal Pulikasi 1, no. 1, 2018, p. 24.

Rozalinda, Islamic Economics: Theory and Its Application in Economic Activity, Jakarta: Raja Grafindo Persada, 2014.

Results of Interview with Syamsuddin as Head of Division of LAZNAS BMH Empowerment South Sulawesi conducted on October 9, 2019

Rusli, dkk, "Impact Analysis of Productive Zakat Capital on Poverty Alleviation in North Aceh District", Jurnal Ilmu Ekonomi 1, no. 1, 2013, p. 58.

Raji, Ismail, Tauhid; It's Implication for Though and Live, Terj. Rahmani Astuti, Bandung: Pustaka Press, 1988.

Shihab, Quraish, Tafsir al-Misbah, Vol. 4, Jakarta: Lentera Hati, 2002.

Sugiarto, Eko, "Welfare Level of Fishermen Community of Benua Baru Ilir Village Based on Statistics Indonesia", EPP 4, no. 2, 2007, p. 32. 
The Distribution of Zakat Mal Based on Al-'Adl in Order to Improve The Welfare of The Mustahiqs in The Laznas of Baitul Mal Hidayatullah South Sulawesi

Shyarif, Muhammad, Ethics and Economics an Islamic Synthesis. terj. Etika dan Ilmu Ekonomi. tt.

Taqiyullah H.O, Zakat and Community Economic Empowerment, Bandung: BAZ Provinsi Jabar, 2004.

The results of an interview with Kadir as chairman of LAZNAS BMH South Sulawesi held on October 9, 2019.

The results of an interview with Ahmad Harun, one of the tough preachers who have been empowered by LAZNAS BMH South Sulawesi on October 15, 2019

The results of an interview with Idris as chairman of LAZNAS BMH South Sulawesi held on October 29, 2019.

Thalib, Hamidy dkk, "Amil's Role as Manager of Zakat to Improve People's Welfare in the City of Bima", Iqtishadia 3, no. 2, 2016, p. 291

Widodo, Hertanto dan Teten Kustiawan, Accounting and Management for Zakat Management Organizations, Ciputat: Institut Manajemen Zakat, 2001.

www.bmh.or.id, diakses tanggal 13 Maret 2019.

Zaman, Hasanuz, Islamic Criteria for the Distribution of Tax Burden, The Mix of Direct and Indirect Taxes the Offsetting Fuction of Zakat, Journal of Islamic Economics 3, no. 1, 1993, p. 95. 